\title{
Diversified Impact of COVID-19 Pandemic on the Overall Health and Well-Being of Children: A Survey Based Case Study
}

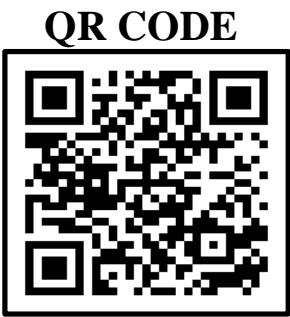

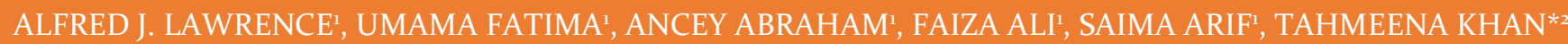

BACKGROUND: COVID-19 pandemic led to the closure of non-essential services including educational institutions and recreational facilities all around the world. The pandemic has affected children at different levels including their mental well- being.

AIM: The objective of this study was to assess the overall impact of the pandemic on the well-being of children in terms of their demographic details, physical activity pattern, sanitary practices, mental health and nutritional practices. 300 children aged between 4-18 years were surveyed through an online survey developed as a Google form.

MATERIAL AND METHODS: Parents or guardians were asked to fill the questionnaire. The questionnaire was approved by Medical doctors for the sake of accuracy and authenticity.

RESULTS: The annual household income of majority of the respondents was between 1-5 lakhs, and they belonged to urban and nuclear households Although modern amenities were available for the children at home, yet majority of them did not have a separate room and a personal smart phone. $89.4 \%$ $(\mathrm{n}=268)$ children used internet for $1-5$ hours every day. $82.4 \%(=247)$ of them were also enrolled in other online courses as well. Lesser time was devoted on physical activity during the pandemic. Negative psychological symptoms like lack in concentration and anxiety, etc. were reported.

CONCLUSION: The paper addresses the changes impacting children's lives at different levels related to their health and well-being. The results must be corroborated with studies reported in literature and may be used for formulating strategies to make children adapt the situation without any negative impact on their personality.

KEYWORDS: COVID-19, Children, Education, Nutrition, Psychological

\section{INTRODUCTION}

With the first reporting of several pneumonia cases on $31^{\text {st }}$ December, 2019 in the Hubei province of China, the novel coronavirus SARS-CoV-2 pandemic gripped the whole world in a matter of months. ${ }^{1}$ Nations affected by the viral disease, implemented stringent lockdown measures leading to the closure of all non-essential services. Measuring children's response to the pandemic is very important as parents and children spend the entire day together in closed confines which may affect the mental well-being adversely and often it goes unnoticed by the parents. To date, no specific evidence-informed guidelines regarding effective strategies have been devised, that adults could use to support children's socio-emotional well-being during the pandemic. Adverse experiences in childhood may have long term psychological consequences and impact. ${ }^{2}$ There is no concrete strategy adopted by the educational institutions, to offer counselling on mental well-being of children. ${ }^{3}$ During the pandemic, the eating and physical activity pattern has also been impacted. ${ }^{4}$ Dietary habits are seldom influenced by psychological factors, and may have long-term health effects. ${ }^{5}$ This study was done as a survey with children to assess the multi-level impact of COVID-19 pandemic on their life. Diversified impact on their physical activity pattern, mental and psychological behaviour and dietary habits was probed through a questionnaire survey.

\section{MATERIAL AND METHODS}

The study was conducted between ist November-15th December, 2020, through an online questionnairebased survey which was drafted as a Google form titled "COVID-19 in context with the overall health of Children" consisting of 67 questions. The study was conducted according to the recommendations of the Helsinki Declaration. The questionnaire was compiled under the guidance of medical doctors and expert psychiatrists. A questionnaire survey offers a practical and inexpensive way to gather data from the target group. In addition to this the data accumulated by the questionnaire can be easily interpreted and analyzed. The study area was Northern India, but the questionnaire was posted on different social media platforms and shared publicly to facilitate snowball sampling. Total 300 responses were accepted as they

(C) Alfred J. Lawrence et al. This is an open access article distributed under the terms of the Creative Commons Attribution License CC-BY-NC 4.o, which permits unrestricted use, distribution and reproduction in any medium, provided the use is not commercial and the original author(s) and source are cited. Submitted on: o8-Sep-2021; Accepted on: 29-Sep-2021 
fulfilled the inclusion criterion, which was based on the age of children (4-18 years). The exclusion criterion was kept less stringent to attain maximum responses and for that very few questions in the questionnaire were made compulsory. Because of this, different responses were received for separate questions and percentage was calculated accordingly. Voluntary answering was sought so as to keep the interest of the respondents intact. Clear instructions were given in the form to the participants related to the purpose of the study and it was agreed that their personal details would be kept confidential and only be used for research purpose. The Google form was designed in five separate sections viz. 1. Demographic details, 2. Change in activity pattern before and during the COVID-19 pandemic, 3. Physical features- Sanitary practices and health history, 4. Mental health of the child before and during the pandemic and, 5. Nutritional aspects related to the health of child before and during the pandemic. All the tabulation, interpretation and analysis of the data were done in Microsoft Excel 2019 (16.0.6742.2048).

\section{RESULTS AND DISCUSSION}

Demographic details: The survey focused on children aged between 4-18 years. Important changes like sphincter control, emotional self-regulation etc. have been observed once a child reaches 4 years of age. On the other hand, after the age of 10, pre-adolescence phase starts which initiates a series of physical and emotional changes leading to physical and emotional changes reorganizing the emotional experience of children and their relationships with others in their surroundings and how they respond to stress. ${ }^{6} 55.6 \%$ $(n=167)$ children were male. $91.6 \%(n=275)$ of them belonged to urban household, having 1-5 members in the family. $71.6 \%(\mathrm{n}=215)$ of them had two siblings. The educational background was also included as it is one of the most important factors influencing the life style and daily choices and practices. $46.4 \%(n=139)$ parents had post graduate level of education and $5.2 \%(n=16)$ had a doctoral degree. $64.6 \%(n=194)$ mothers of the surveyed children were homemakers. Mostly up to five rooms were there in the house as reported by $67.6 \%$ $(n=203)$ respondents. However, mostly children did not have a separate room. Modern amenities like smart phone (71.8\%), Smart T.V. (43.5\%) and laptop (41.8\%) etc. were available at home to be accessed by the child, however personal smart phone was not allowed for the child as reported by $90.4 \%(\mathrm{n}=\mathbf{2 7 1})$ of the respondents. $84.3 \%(n=145)$ children used the internet frequently for educational and other purposes. $40.9 \%$ of them used internet as a medium for entertainment (figure 1). The use of smart phones or social media among children was not encouraged earlier by the parents, and in the wake of the pandemic situation, these have become the only way of entertainment, education and information. ${ }^{7}$ Cartoon shows (77.9\%), movie and music channels (33.8\%) and family shows (24\%) were the most watched content. WhatsApp was the most common social media platform accessed by the children as reported by $35.6 \%$ respondents. The internet surfing was done under the supervision of their parents as reported by $72.4 \%(n=217)$ of the respondents, which was appreciable as parents must keep a tab on the judicious use of electronic media and devices and must be aware of the content their child is exposed to. ${ }^{8}$ There may be some disparity owing to differential household income, access to technology, and other factors like area of the household, and neighbourhood conditions. ${ }^{9}$ Recreational facilities like cycle and music system were also available at home. $75.4 \%(n=226)$ children also indulged in indoor games. Parents must try to involve their children in indoor games which are enjoyable and educational at the same time. ${ }^{10}$ A healthy atmosphere at home can be created by initiating emotional and amiable interaction between the children and their parents which may serve as a stress buster. The demographic details are given in Table 1. The Internet exposure details are given in Table 2. Family and household details are given in Table 3 and details regarding amenities accessed by the child are given in table 4 .

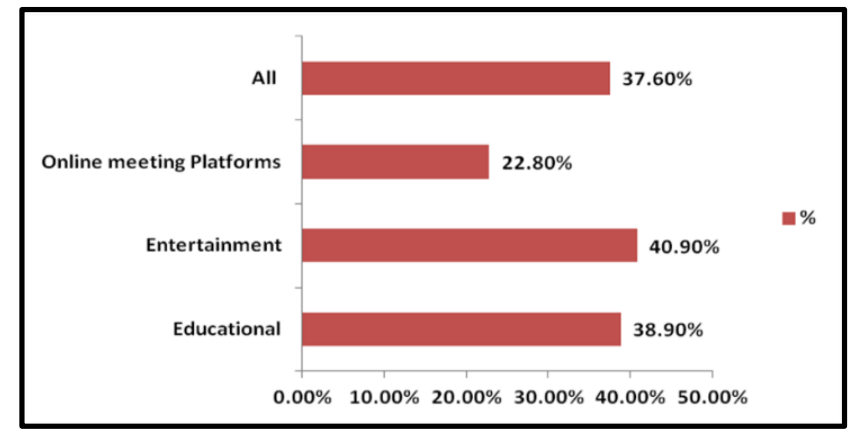

Figure 1. Usage of internet for different purposes

Changes in activity pattern before and during the COVID-19 pandemic: Questions pertaining to the changes and variation in the activity pattern were included to know whether there were any significant changes in the day-to-day routine of the children. Variation in the hours of sleep was observed during the COVID-19 pandemic scenario. Healthy behaviours are usually obtained during the structured days including 


\begin{tabular}{|c|c|c|}
\hline Age of Children & \multicolumn{3}{c|}{} \\
\hline Age & $\%$ & Respondents \\
\hline 4 - 10 Years & 29.4 & 88 \\
\hline 11-15 Years & 63.6 & 191 \\
\hline 15-18 Years & 7 & 21 \\
\hline \multicolumn{2}{|c|}{ Sex of Children } \\
\hline Sex & $\%$ & Respondents \\
\hline Male & 55.6 & 167 \\
\hline Female & 44.4 & 133 \\
\hline \multicolumn{2}{|c|}{ Country of Residence } \\
\hline Country & $\%$ & Respondents \\
\hline India & 89.4 & 268 \\
\hline Others & 10.6 & 32 \\
\hline \multicolumn{2}{|c|}{ Nature of Family } & \\
\hline Nature & $\%$ & Respondents \\
\hline Rural & 8.4 & 15 \\
\hline Urban & 91.6 & 275 \\
\hline Nuclear & 59 & 177 \\
\hline Joint & 41 & 123 \\
\hline
\end{tabular}

Table 1. Demographic Details

school opening days as compared to unstructured days which include weekends or vacations. ${ }^{\text {" }}$ Majority $(\mathrm{n}=279)$ of children, spent 1-2 hours in physical activity during the pandemic, although due to the closure of schools they had more time to indulge in physical activity. Insufficient physical activity during childhood may lead to serious health outcomes in adulthood as obesity, type II diabetes, and metabolic syndrome. ${ }^{12}$ The frequency of the time spent with friends in person decreased significantly during the pandemic, whereas the use of virtual platforms for interaction increased, as $25.3 \%(n=76)$ children devoted more than 5 hours every week on virtual interaction. One to three hours were spent on watching television as reported by $81.6 \%$ $(\mathrm{n}=245)$ respondents, whereas $18.4 \%(\mathrm{n}=56)$ children devoted more than three hours in watching television or surfing OTT platforms for entertainment. The increase in recreational screen time is in tandem with the studies reported from Spain ${ }^{13}$ and China. ${ }^{14}$ According to a study conducted in Germany, the nonrecreational screen time including social media usage increased from 215 to 338 minutes daily during the strict lockdown implementation. ${ }^{15}$ Overall as compared to the time devoted for physical activity, more time was spent on screen time, which is very alarming. The variation in physical activity pattern is given in Table 5 .

Physical characteristics, Sanitary and health practices: Average height and weight of the

\begin{tabular}{|c|c|c|}
\hline \multicolumn{3}{|c|}{ Does the child surf internet } \\
\hline Response & $\%$ & Respondents \\
\hline Yes & $84 \cdot 3$ & 253 \\
\hline No & 15.7 & 47 \\
\hline \multicolumn{3}{|c|}{ Number of hours spent on internet surfing } \\
\hline Number of Hours & $\%$ & Respondents \\
\hline $1-6$ & 90 & 270 \\
\hline More Than 6 & 10 & 30 \\
\hline \multicolumn{3}{|c|}{ Is child active on Social Media } \\
\hline Response & $\%$ & $\%$ \\
\hline Yes & 24.4 & 73 \\
\hline No & 75.6 & 227 \\
\hline \multicolumn{3}{|c|}{ Time Spent on online school classes } \\
\hline Number of Hours & $\%$ & Respondents \\
\hline $1-5$ & 89.4 & 268 \\
\hline More Than 5 & 10.6 & 32 \\
\hline \multicolumn{3}{|c|}{ Additional courses taken online } \\
\hline Response & $\%$ & Respondents \\
\hline Yes & 82.4 & 247 \\
\hline No & 17.6 & 53 \\
\hline \multicolumn{3}{|c|}{ How are online Classes attended } \\
\hline Response & $\%$ & Respondents \\
\hline $\begin{array}{c}\text { Under The } \\
\text { Supervision Of } \\
\text { Parents }\end{array}$ & 72.4 & 217 \\
\hline $\begin{array}{l}\text { The Child Attends } \\
\text { It Alone }\end{array}$ & 27.6 & 83 \\
\hline
\end{tabular}

Table 2. Internet Exposure among the Children

participating children was found to be between 120-160 $\mathrm{cm} \& 20-60 \mathrm{~kg}$ respectively. However, few of them were found to be underweight weighing as less as $13 \mathrm{~kg}$, and some of them were overweight having maximum weight of $84 \mathrm{~kg}$. Bathing frequency increased during the pandemic. Similarly, as compared to pre-pandemic situation, 38.3\% $(\mathrm{n}=115)$ children sanitized their hands 6-10 times, and $19.4 \%(n=58)$ sanitized their hands more than 10 times a day. Loss of appetite (6.8\%), muscle or body ache $(6.7 \%)$, fatigue or excessive sleepiness $(8.6 \%)$ were some of the symptoms which were more frequently reported during the pandemic. $87.6 \%(n=263)$ of the children were found to be nonallergic, however those who were cited dust, pollen, pollution, washing powder and Aloe barbadensis as the common sources of allergens. The details of the sanitary and hygiene practices are given in Table 6.

Mental health of the children: Children are as much at the risk for negative psychological impact as adults during a crisis. Children as young as two-year-old are aware of the changes taking place in their 


\begin{tabular}{|c|c|c|}
\hline \multicolumn{3}{|c|}{ Mothers - Working Or Homemakers } \\
\hline Response & $\%$ & Respondents \\
\hline Working & $35 \cdot 4$ & 106 \\
\hline Homemaker & 64.6 & 194 \\
\hline \multicolumn{3}{|c|}{ Total Annual Income } \\
\hline Annual Income & $\%$ & Respondents \\
\hline Less than 1 Lakh & 7 & 21 \\
\hline $1-5$ Lakhs & 49 & 147 \\
\hline 5-9 Lakhs & 22.4 & 67 \\
\hline 10 Lakhs or Above & 21.6 & 65 \\
\hline \multicolumn{3}{|c|}{$\begin{array}{l}\text { Parent's Education } \\
\end{array}$} \\
\hline Educational Level & $\%$ & Respondents \\
\hline $\begin{array}{l}\text { High School - } \\
\text { Intermediate } \\
\end{array}$ & 3.4 & 10 \\
\hline Graduate & 45 & 135 \\
\hline Post Graduate & 46.4 & 139 \\
\hline Doctorate & 5.2 & 16 \\
\hline \multicolumn{3}{|c|}{ Total Members In The Family } \\
\hline $\begin{array}{l}\text { Number of } \\
\text { Members }\end{array}$ & $\%$ & Respondents \\
\hline $1-5$ & 55.6 & 167 \\
\hline More Than 5 & $44 \cdot 4$ & 133 \\
\hline \multicolumn{3}{|c|}{ Number of Siblings } \\
\hline $\begin{array}{c}\text { Number of } \\
\text { Siblings } \\
\end{array}$ & $\%$ & Respondents \\
\hline None & 28.4 & 85 \\
\hline $1-2$ & 71.6 & 215 \\
\hline
\end{tabular}

Table 3. Family and Household Details of the Children

surroundings, ${ }^{16}$ therefore questions pertaining to behavioural changes, temperamental traits and peculiarities were added in the questionnaire. Multiple option selection was kept in the section for thorough assessment. The prominent behavioural changes during the pandemic were difficulty in concentration, anger management and getting worried (Table 7). Children are fearful about self infection and anxious for the safety of their family members. ${ }^{17}$ They also feel isolated due to the closure of their schools, recreational facilities and restriction to meet their friends. ${ }^{17}$ The noteworthy temperamental changes taking place during the pandemic were lethargy, as reported by $8.5 \%$ respondents. Although the social-distancing measures were essential to curb the infection, they might have hampered the physical fitness level of the children. ${ }^{18}$ It has also been argued that the closure of schools and low physical activity and sedentary time

\begin{tabular}{|c|c|c|}
\hline \multicolumn{3}{|c|}{ Number of Rooms in home } \\
\hline Number of Rooms & $\%$ & Respondents \\
\hline $1-5$ & 67.6 & 203 \\
\hline More Than 5 & 32.4 & 97 \\
\hline \multicolumn{3}{|c|}{ Does the Child Have A Separate Room } \\
\hline Response & $\%$ & Respondents \\
\hline Yes & 31 & 93 \\
\hline No & 69 & 207 \\
\hline \multicolumn{3}{|c|}{$\begin{array}{c}\text { Recreational Facilities Available At Home For } \\
\text { The Child (Multiple choice question) }\end{array}$} \\
\hline Facilities Available & $\%$ & Respondents \\
\hline Cycle & 91.6 & 275 \\
\hline Music System & 41 & 123 \\
\hline Gaming Stations & 19.6 & 59 \\
\hline \multicolumn{3}{|c|}{ Does The Child Indulge In Indoor Games } \\
\hline Response & $\%$ & Respondents \\
\hline Yes & $75 \cdot 4$ & 226 \\
\hline No & 24.6 & 74 \\
\hline \multicolumn{3}{|c|}{ Indulgence in type of Indoor Games } \\
\hline Response & $\%$ & Respondents \\
\hline Ludo, Carom, Chess & 92.4 & 277 \\
\hline Others & $7 \cdot 6$ & 23 \\
\hline \multicolumn{3}{|c|}{ Does The Child Owns Personal Smartphone } \\
\hline Response & $\%$ & Respondents \\
\hline Yes & 9.6 & 29 \\
\hline No & 90.4 & 271 \\
\hline
\end{tabular}

Table 4. Modern Amenities accessed by the Child

may lead to increased risk of obesity..$^{18}$ Sadness (6.5\%), quarrelsome nature $(6.3 \%)$, and self-centred tendency (4.05\%) were some other symptoms observed in the children showing their poor mental health (Figure 2). It was also found that children became more reserved and isolated. The self-confidence level was also found to be low. Tendency to isolate is not considered as a good sign because social interactions are necessary to inculcate cultural values and social norms. ${ }^{19}$ Mood swings reported by $60.4 \% \quad(\mathrm{n}=55) \quad$ respondents, homesickness (34.1\%), stubbornness (31.9\%) and anxiety $(16.5 \%)$ were the prominent temperamental peculiarities observed during the pandemic (Figure 3). The symptoms were in line with the previous studies conducted in Italy and Spain ${ }^{20}$ to assess the emotional impact of quarantine on children. $85 \%$ of the parents 


\begin{tabular}{|c|c|c|c|c|}
\hline \multirow[t]{2}{*}{ Hours of sleep } & \multicolumn{2}{|c|}{ Before COVID -19 } & \multicolumn{2}{|c|}{ During COVID- 19} \\
\hline & $\%$ & Respondents & $\%$ & Respondents \\
\hline $8-10$ hours & 96.4 & 289 & 83 & 249 \\
\hline More than 10 hours & 3.6 & 11 & 17 & 51 \\
\hline \multicolumn{5}{|c|}{ Time spent on physical activity per day (outdoor games) } \\
\hline \multirow[t]{2}{*}{ Hours of physical activity } & \multicolumn{2}{|c|}{ Before COVID-19 } & \multicolumn{2}{|c|}{ During COVID-19 } \\
\hline & $\%$ & Respondents & $\%$ & Respondents \\
\hline $1-4$ hours & 93 & 279 & 93.7 & 281 \\
\hline More than 4 hours & 7 & 21 & 6.3 & 19 \\
\hline \multicolumn{5}{|c|}{ Frequency of spending time with friends in person } \\
\hline \multirow[t]{2}{*}{ Number of times per month } & \multicolumn{2}{|c|}{ Before COVID-19 } & \multicolumn{2}{|c|}{ During COVID-19 } \\
\hline & $\%$ & Respondents & $\%$ & Respondents \\
\hline $1-7$ & $87 \cdot 3$ & 262 & 73.4 & 220 \\
\hline More than 7 times & 9 & 27 & 1 & 3 \\
\hline Not frequently & 3.6 & 11 & 25.6 & 77 \\
\hline \multicolumn{5}{|c|}{ Frequency of spending time with friends on virtual platforms } \\
\hline \multirow[t]{2}{*}{ Number of hours spent per week } & \multicolumn{2}{|c|}{ Before COVID-19 } & \multicolumn{2}{|c|}{ During COVID-19 } \\
\hline & $\%$ & Respondents & $\%$ & Respondents \\
\hline Less than 5 hours & 95.6 & 287 & 63.6 & 191 \\
\hline 5 Hours & 3.33 & 10 & $25 \cdot 3$ & 76 \\
\hline More than 5 hours & 1 & 3 & 11.1 & 33 \\
\hline \multicolumn{5}{|c|}{ Time spent watching T.V./OTT per day } \\
\hline Number of hours & \multicolumn{2}{|c|}{$\%$} & \multicolumn{2}{|c|}{ Respondents } \\
\hline $1-3$ hours & \multicolumn{2}{|c|}{81.6} & \multicolumn{2}{|c|}{245} \\
\hline More than 3 hours & \multicolumn{2}{|c|}{18.4} & \multicolumn{2}{|c|}{55} \\
\hline
\end{tabular}

Table 5. Change In Activity Pattern Before and During the COVID-19 Pandemic

reported worsening of the emotional and behavioural symptoms in children. Studies conducted with children from Asia have shown greater prevalence of psychological issues as compared to developed countries in the initial stages of the pandemic. Children when kept in dark about the happenings in the community tend to be more worried and angrier, and throw tantrums, hence it must be the duty of their

\begin{tabular}{|c|c|c|c|c|}
\hline \multicolumn{5}{|c|}{ Number of times the child takes bath } \\
\hline \multirow[t]{2}{*}{ Frequency of Taking Bath } & \multicolumn{2}{|c|}{ Before COVID-19 } & \multicolumn{2}{|c|}{ During COVID-19 } \\
\hline & $\%$ & Respondents & $\%$ & Respondents \\
\hline I time & 71.6 & 215 & 70 & 210 \\
\hline 2 times & 19 & 57 & 28.4 & 85 \\
\hline More than 2 times & 9.4 & 28 & 1.6 & 5 \\
\hline \multicolumn{5}{|c|}{ Number of times the child washes or sanitizes hands } \\
\hline Frequency of Washing or & \multicolumn{2}{|c|}{ Before COVID-19 } & \multicolumn{2}{|c|}{ During COVID-19 } \\
\hline & $\%$ & Respondents & $\%$ & Respondents \\
\hline $1-5$ Times & $89 \cdot 4$ & 268 & 42.3 & 127 \\
\hline $6-10$ Times & 8.4 & 25 & 38.3 & 115 \\
\hline More than 10 Times & 2.2 & 7 & 19.4 & 58 \\
\hline \multicolumn{5}{|c|}{ If child is allergic to something } \\
\hline Response & \multicolumn{2}{|c|}{$\%$} & \multicolumn{2}{|c|}{ Respondents } \\
\hline Yes & \multicolumn{2}{|c|}{12.4} & \multicolumn{2}{|c|}{19} \\
\hline No & \multicolumn{2}{|c|}{87.6} & \multicolumn{2}{|c|}{263} \\
\hline \multicolumn{5}{|c|}{ Did the child come in contact with someone who tested Positive for COVID-19 } \\
\hline Response & \multicolumn{2}{|c|}{$\%$} & \multicolumn{2}{|c|}{ Respondents } \\
\hline Yes & \multirow{2}{*}{\multicolumn{2}{|c|}{$\begin{array}{c}4 \\
06\end{array}$}} & \multicolumn{2}{|c|}{12} \\
\hline No & & & \multicolumn{2}{|c|}{288} \\
\hline
\end{tabular}

Table 6. Sanitary and Hygiene practices of the Children 


\begin{tabular}{|c|c|c|c|c|}
\hline \multirow[t]{2}{*}{$\begin{array}{l}\text { Behaviour- } \\
\text { al Changes }\end{array}$} & \multicolumn{2}{|c|}{$\begin{array}{c}\text { Before COVID- } \\
19 \\
\text { Multiple } \\
\text { choices } \\
\text { allowed }\end{array}$} & \multicolumn{2}{|c|}{$\begin{array}{l}\text { During COVID-19 } \\
\text { Multiple choices } \\
\text { allowed }\end{array}$} \\
\hline & $\%$ & $\begin{array}{l}\text { Responde } \\
\text { nts }\end{array}$ & $\%$ & Respondents \\
\hline $\begin{array}{l}\text { Change in } \\
\text { concentrat } \\
\text { ion and } \\
\text { Attention } \\
\end{array}$ & 11.8 & 17 & 20.3 & 72 \\
\hline $\begin{array}{c}\text { Gets } \\
\text { Worried } \\
\end{array}$ & 8.3 & 12 & 10.7 & 38 \\
\hline Gets Angry & 10.4 & 15 & 14.9 & 53 \\
\hline $\begin{array}{c}\text { Tries to } \\
\text { Avoid }\end{array}$ & $5 \cdot 5$ & 8 & 8.47 & 30 \\
\hline $\begin{array}{c}\text { Remains } \\
\text { Isolated }\end{array}$ & 6.9 & 10 & 9.03 & 32 \\
\hline $\begin{array}{c}\text { Gets } \\
\text { Distracted }\end{array}$ & 13.2 & 19 & 10.4 & 37 \\
\hline $\begin{array}{c}\text { Seems to } \\
\text { have lesser } \\
\text { fun } \\
\end{array}$ & $9 \cdot 7$ & 14 & 16.1 & 57 \\
\hline $\begin{array}{c}\text { Is } \\
\text { emotionall } \\
\text { y balanced }\end{array}$ & $33 \cdot 5$ & 48 & 9.8 & 35 \\
\hline \multicolumn{5}{|c|}{ Any Death in Family/ Locality Due To COVID-19 } \\
\hline $\begin{array}{c}\text { Respo } \\
\text { nse }\end{array}$ & \multicolumn{2}{|c|}{$\%$} & \multicolumn{2}{|c|}{ Respondents } \\
\hline Yes & \multicolumn{2}{|c|}{2.4} & \multicolumn{2}{|r|}{7} \\
\hline No & \multicolumn{2}{|c|}{97.6} & \multicolumn{2}{|r|}{293} \\
\hline
\end{tabular}

Table 7. Behavioural Changes Observed in Children

parents to acknowledge and validate their feelings and make them understand the scenario and importance of social-distancing and safety measures. Previous studies undertaken during past pandemics like SARS and MERS have shown that quarantined children showed symptoms of anxiety, depression, irritability, mood swings and sleep disturbances etc. ${ }^{21}$ They may also be worried due to interrupted academic schedules and future uncertainty. Public health authorities and clinicians must have an accurate estimate of the behavioural peculiarities and psychopathologies in children.

Nutritional Aspects: Young children have constituted a very meagre percentage of COVID-19 infections, as kids' immune system is better equipped to combat the infection than adults. However some studies contradict the same. A study with COVID-19 infection including 65 children found that the adults had a stronger $\mathrm{T}$-cell response to the virus spike protein than the children and young adults. ${ }^{22}$ The lockdown has impacted the daily life at different levels, including nutrition, dietary habits and variation have emphasized on the crucial role of physical activity and nutrition in the prevention of nontransmissible chronic diseases. Data has also been published related to the dietary recommendation and nutrition to curb the infection as diet and its quality is related to the overall health of a human being. During the pandemic, $32.4 \%(\mathrm{n}=97)$ of the children took more than three meals per day as compared to $9.7 \%(n=29)$ before the pandemic (Table 8 ). The home-made junk food was most preferred as reported by $76.1 \%(n=121)$ respondents. The intake of junk food increased considerably during the lockdown as reported by $88 \%$ of the respondents (Figure 4). Food choices are seldom influenced by psychological factors, and may be probed to know their long-term health effects. ${ }^{5}$ Food cravings may be triggered by mental health issues like stress, social isolation or lack of physical activity. ${ }^{5}$ Changes in eating pattern or psychological issues faced during the

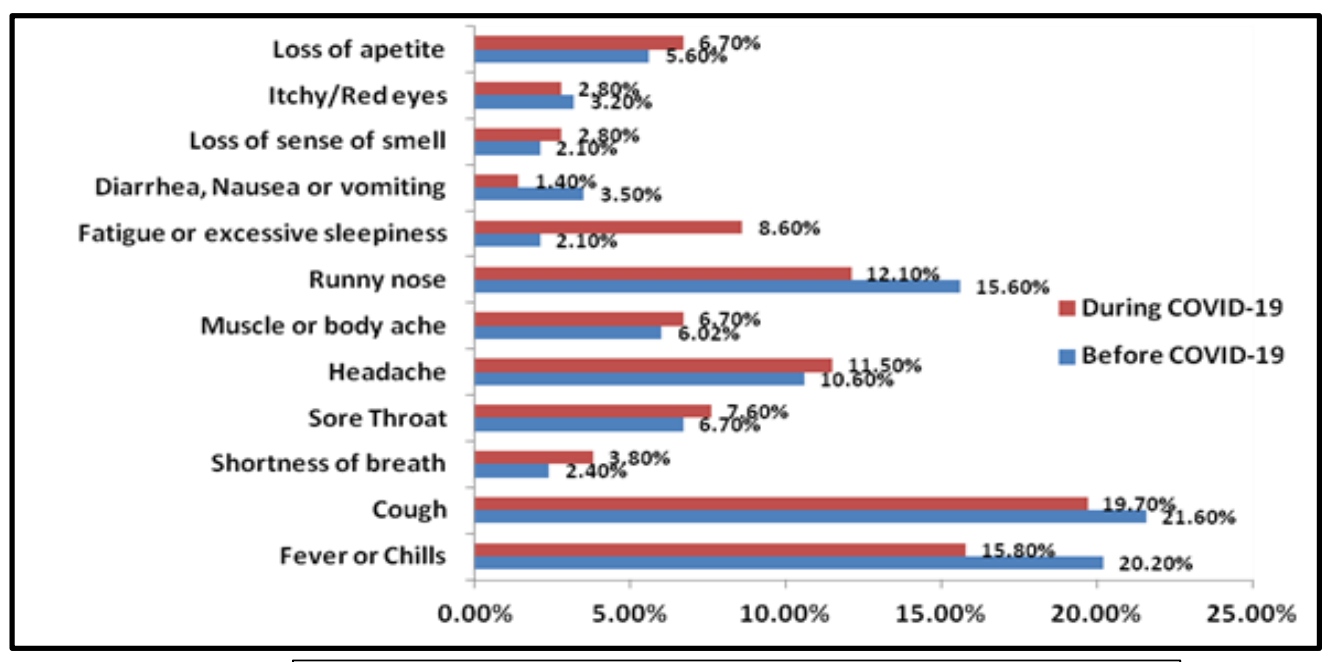

Figure 2. Occurrence of Different Symptoms in Children 


\begin{tabular}{|c|c|c|c|c|}
\hline \multicolumn{5}{|c|}{ Number of Meals Taken } \\
\hline Number of Meals & \multicolumn{2}{|c|}{ Before COVID-19 } & \multicolumn{2}{|c|}{ During COVID-19 } \\
\hline & $\%$ & Respondents & $\%$ & Respondents \\
\hline 3 Meals Per Day & 90.3 & 271 & 67.6 & 203 \\
\hline More Than 3 Meals Per Day & $9 \cdot 7$ & 29 & 32.4 & 97 \\
\hline \multicolumn{5}{|c|}{ Fruit Intake Of The Child } \\
\hline \multirow[t]{2}{*}{ Fruit Intake } & \multicolumn{2}{|c|}{ Before COVID-19 } & \multicolumn{2}{|c|}{ During COVID-19 } \\
\hline & $\%$ & Respondents & $\%$ & Respondents \\
\hline More & 59.6 & 179 & 91.6 & 275 \\
\hline Less & 40.4 & 121 & 8.4 & 25 \\
\hline \multicolumn{5}{|c|}{ Inclusion of Vitamin C In the Diet of Child } \\
\hline \multirow[t]{2}{*}{ Vitamin C Inclusion } & \multicolumn{2}{|c|}{ Before COVID-19 } & \multicolumn{2}{|c|}{ During COVID-19 } \\
\hline & $\%$ & Respondents & $\%$ & Respondents \\
\hline Yes & 70.6 & 212 & $94 \cdot 3$ & 283 \\
\hline \multirow[t]{2}{*}{ No } & 29.4 & 88 & $5 \cdot 7$ & 17 \\
\hline & \multicolumn{4}{|c|}{ Intake of Any Vitamin Supplements By The Child } \\
\hline \multirow[t]{2}{*}{ Vitamin Intake } & \multicolumn{2}{|c|}{ Before COVID-19 } & \multicolumn{2}{|c|}{ During COVID- 19} \\
\hline & $\%$ & Respondents & $\%$ & Respondents \\
\hline Yes & $25 \cdot 7$ & 77 & $59 \cdot 3$ & 178 \\
\hline No & $74 \cdot 3$ & 223 & 40.7 & 122 \\
\hline \multicolumn{5}{|c|}{ Any Other Preventive Measures Taken During The Pandemic } \\
\hline Response & \multicolumn{2}{|c|}{$\%$} & \multicolumn{2}{|c|}{ Respondents } \\
\hline Yes & \multicolumn{2}{|c|}{$79 \cdot 3$} & \multicolumn{2}{|c|}{238} \\
\hline No & \multicolumn{2}{|c|}{20.7} & \multicolumn{2}{|c|}{62} \\
\hline
\end{tabular}

Table 8. Nutritional Aspects Related to the Health of the Child Before and During the Pandemic

pandemic time could have a negative impact on children's self esteem and self efficacy ${ }^{23}$, which in turn has the potential to weaken the immune system. Although children did not prefer to have fruits, still as reported by $91.6 \%(n=275)$ respondents, the fruit intake increased during the pandemic. Vitamin $\mathrm{C}$ was also included in diet in $94.3 \%(n=283)$ children. Enhancing immunity is an important way to prevent and manage viral infections. Nutritional status influences immune homeostasis, while malnutrition weakens the immune response to pathogens. ${ }^{24}$ Vitamins and trace elements are relatively essential for the upholding of immune system. Therefore intake of vitamins and trace elements may improve immunity against COVID-19. The common sources of Vitamin $C$ were lemon, orange, tomatoes, and kiwi etc. However, some respondents revealed to have included dietary supplements as a source of Vitamin C.
Majority of the respondents acknowledged that no side effects were found to be associated with the consumption of these supplements, in some cases however, indigestion was the common symptom reported as a side effect. Rs. 5000-7000 were allocated for the monthly budget spent on nutrition and precautionary measures, however Rs. 15,000 was the maximum amount spent per month.

Limitations of the study: The survey only included those who attempted and submitted the questionnaire. Those who saw and chose not to participate could not be determined. However it may be said that those who were interested in physical activity and their health and hygiene took part in the online survey. However, previous studies have suggested that the quality of responses may be reduced in online surveys. Since the 


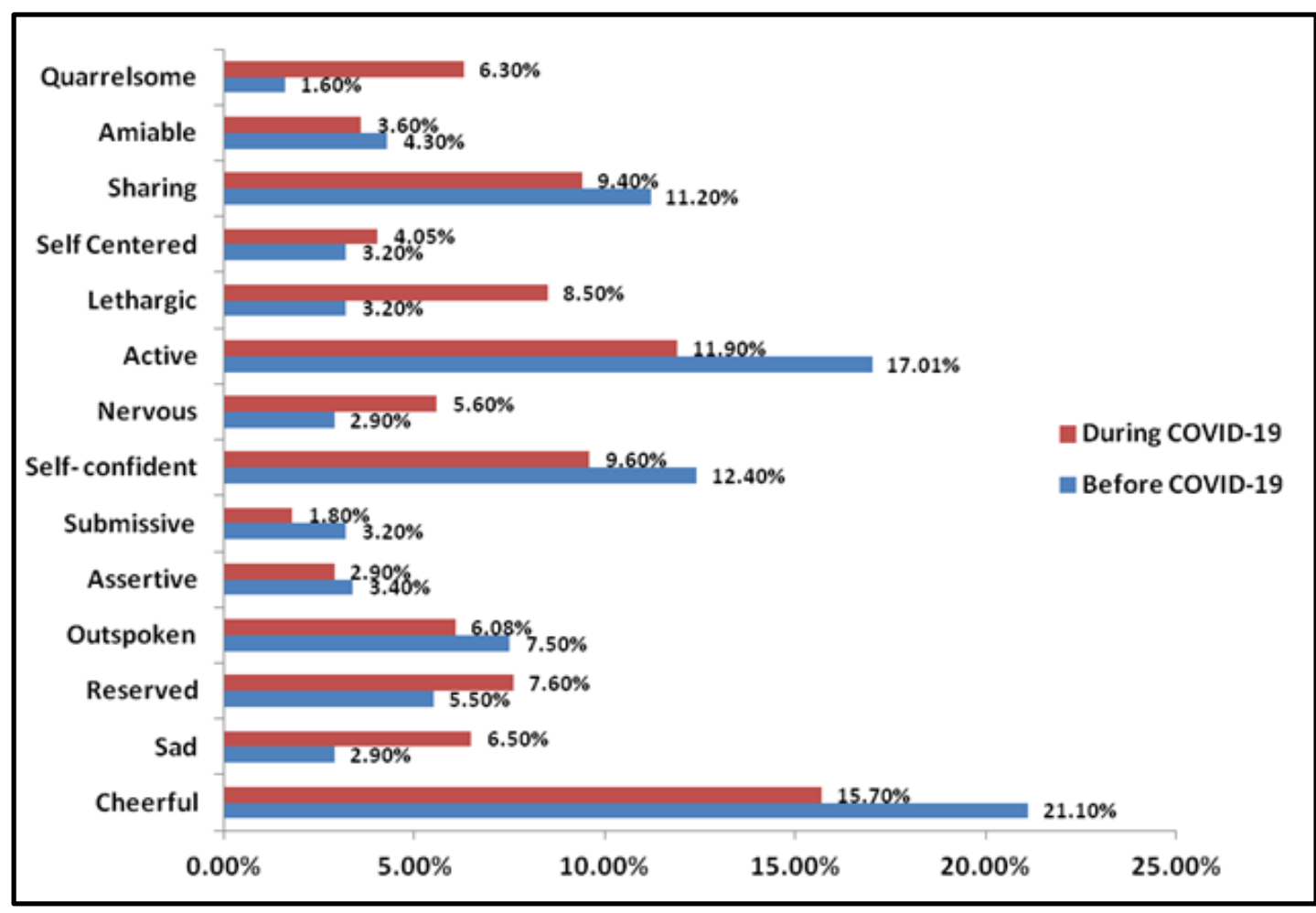

Figure 3. Behavioural Changes Observed in Children

results of these surveys are direct, the results should be carefully interpreted considering all the limitations. The mere questionnaire findings do not guarantee the authenticity of the results and the findings must be verified by a suitable scientific method. Experimental observation and empirical evidences must also be collected along with repeated assessment. There are several other drawbacks associated with the online survey which must be taken into consideration before the interpretation of the results. There is a high probability that the respondent filled one questionnaire

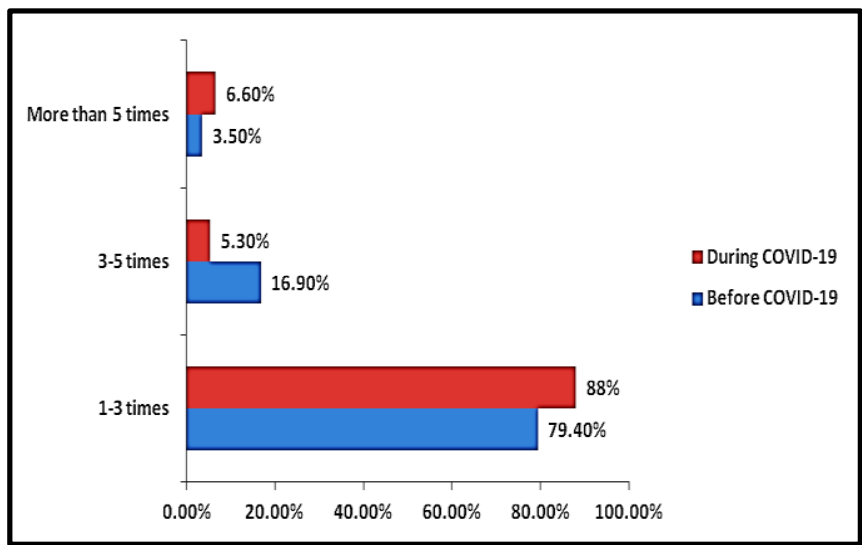

Figure 4. Frequency of intake of Junk Food in Children for all the children in home in a generalized way. Several surrounding factors like noise, unavoidable interruptions and presence of family members may have influenced the concentration of the respondent while answering the questions. Access to internet and the link for the questionnaire was another factor of importance.

\section{CONCLUSION}

The comprehensive online survey was done to assess the overall impact of the pandemic and the imposed lockdown on the well-being of children. The thorough assessment was made on different aspects including demographic details, activity pattern, mental health and nutritional variation and food preferences. Majority of the children belonged to urban nuclear households having access to modern amenities like smart phone, internet, Wi-Fi connection and smart T.V. Children were found to surf internet frequently, but under the observation of their parents. Negative psychological traits like difficulty in concentration, stubbornness, mood swings, and anxiety were some of the common symptoms observed in the children. There was a significant variation in the sleep pattern. Improved sanitary practices were also observed as majority of the surveyed children washed or sanitized their hands 6-10 
times a day. Consumption of home made junk food enhanced by a significant percentage which may be also linked to the negative psychological impact.

\section{RECOMMENDATION}

The study has highlighted the fact that the children and their adaptive behaviour have been affected by the change in the scenario owing to the pandemic. There is an urgent need for health authorities and government in collaboration and coordination with educational institutions to provide adequate psychological interventions along with educational and recreational measures. For a thorough assessment of the mental health and its associated impact on the dietary habits of the children, paediatricians, psychiatrists and psychologists must work together to reach out to the needful. Not only this, response of parents to the pandemic must also be assessed as it is a crucial and decisive factor to know their approach towards their children.

\section{REFERENCES}

1. Lv M, Luo X, Estill J, Liu Y, Ren M, Wang J, et al. Coronavirus disease (COVID-19): a scoping review. Euro Surveill, 2020; 25(15): 2000125. https://doi.org/10.2807/156o-7917.ES.2020.25.15.2000125. 2. Ports KA, Ford DC, Merrick MT. Adverse childhood experiences and sexual victimization in adulthood. Child Abuse \& Neglect: The International Journal. 2016; 51: 31322. https://doi.org/10.1016/j.chiabu.2015.08.017. Epub 2015 Sep 19.

3. Karam EG, Friedman MJ, Hill ED, Kessler RC, McLaughlin KA, Petukhova M, et al. Cumulative traumas and risk thresholds: 12-month PTSD in the World Mental Health (WMH) surveys. Depression and Anxiety, 2014; 31(12): 130-42. https://doi.org/10.1002/da.22169.

4. Stockwell S, Trott M, Tully M, Shin J, Barnett Y, Butler $\mathrm{L}$, et al. Changes in physical activity and sedentary behaviours from before to during the COVID-19 pandemic lockdown: a systematic review. BMJ Open Sports and Exercise Medicine, 2021; 7(1):eooog6o. http://doi.org/10.1136/bmjsem-2020-00096o

5. Naja F, Hamadeh R. Nutrition amid the COVID-19 pandemic: A multi-level framework for action. European Journal of Clinical Nutrition, 2020; 74(8): 1117-21. https://doi.org/10.1038/s41430-020-0634-3.

6. Greenberg R. Children and Families. Women \& Therapy,2008:29: 165.

7. Saxena R, Saxena SK. Preparing children for pandemics. Coronavirus Disease 2019 (COVID-19), 2020; 30: 187. https://doi.org/10.1007/978-981-15-4814-7_15
8. Kudchadkar SR, Carroll CL. Using social media for rapid information dissemination in a pandemic: peds ICU and Coronavirus Disease 2019. Pediatric Critical Care Medicine, 2020; 21(8): 538-46. https://doi.org/10.1097/PCC.oooooooooooo2474.

9. Woo BJ, Chang J, Hulse E, Turetsky R, Parkinson K, Rausch J. Zooming towards a telehealth solution for vulnerable children with obesity during COVID-19. Obesity, 2020; 28(7): 1184-86. https://doi.org/10.1002/oby.2286o

10. Fegert JM, Vitiello B, Clemens V. Challenges and burden of the Coronavirus 2019 (COVID-19) pandemic for child and adolescent mental health: a narrative review to highlight clinical and research needs in the acute phase and the long return to normality. Child and Adolescent Psychiatry and Mental Health, 2020; 14(1): 20. https://doi.org/10.1186/s13034-020-00329-3

11. Nagy LC, Faisal M, Horne M, Collings P, Barber S, Mohammed M. Factors associated with accelerometer measured movement behaviours among White British and South Asian children aged 6-8 years during school terms and school holidays. BMJ Open, 2019; 9(8): e025071. https://doi.org/10.1136/bmjopen-2018-025071 12. Jacob L, Tully MA, Barnett Y. The relationship between physical activity and mental health in a sample of the UK public: a cross-sectional study during the implementation of COVID-19 social distancing measures. Mental Health and Physical Activity, 2020; 19(9):

100345 . https://doi.org/10.1016/j.mhpa.2020.100345

13. Bueno RL, Sanchez GFL, Smith L. Health-related behaviors among school-aged children and adolescents during the Spanish Covid-19 confinement. Frontiers in Pediatrics, $\quad 2020 ; \quad 8$ : 573. https://doi.org/10.3389/fped.2020.00573

14. Xiang M, Zhang Z, Kuwahara K. Impact of COVID-19 pandemic on children and adolescents' lifestyle behavior larger than expected. Progress in Cardiovascular Diseases, 2020; 63(4): 531. Bueno RL, Sanchez GFL, Smith L. Health-related behaviors among school-aged children and adolescents during the Spanish Covid-19 confinement. Frontiers in Pediatrics, 2020; 8: https://doi.org/10.1016/j.pcad.2020.04.013

15. Schmidt SCE, Anedda B, Burchartz A, Eichsteller A, Kolb S, Nigg C, et al. Physical activity and screen time of children and adolescents before and during the COVID19 lockdown in Germany: a natural experiment. Scientific Reports, 2020; 10(1):21780. https://doi.org/10.1038/s41598-020-78438-4

16. Imran N, Zeshan M, Pervaiz Z. Mental health considerations for children \& adolescents in COVID-19 Pandemic. Pakistan Journal of Medical Sciences, 2020; 
36:S67. https://doi.org/10.12669/pjms.36.COVID19-

S4.2759

17. Hou T-Y, Mao X-F, Dong W, Cai W-P, Deng G-H. Prevalence of and factors associated with mental health problems and suicidality among senior high school students in rural China during the COVID-19 outbreak. Asian Journal of Psychiatry, 2020; 54:102305. https://doi.org/10.1016/j.ajp.2020.102305

18. Rowlands AV, Pilgrim EL, Eston RG. Patterns of habitual activity across weekdays and weekend days in 9-11-year-old children. Preventive Medicine, 2008; 46(4):317. https://doi.org/10.1016/j.ypmed.2007.11.004 19. Brown E, Chen D, Davies I, Urbina Garcia A, \& Munguia Godinez I. Educating young people about society in China, England, Mexico and Spain: similar approaches to values education from different contexts. Compare: A Journal of Comparative and International Education, 2019; 51(1). https://doi.org/10.108o/03057925.2019.1647513

20. Orgile's M, Morales A, Delvecchio E, Mazzeschi C, Espada JP. Immediate psychological effects of the COVID-19 quarantine in youth from Italy and Spain. Frontiers in Psychology, 2020; 11:579038. https://doi.org/10.3389/fpsyg.2020.579038
21. Denis-Ramirez E, Sorensen KH, Skovdal M. In the midst of a 'perfect storm': Unpacking the causes and consequences of Ebola-related stigma for children orphaned by Ebola in Sierra Leone. Children and Youth Services Review, 2017; 73:445. https://doi.org/10.1016/j.childyouth.2016.11.025

22. Pierce CA, Hurlburt, PP, Yile D, Aschner CB, Cheshenko N, Galen B. Immune responses to SARS-CoV2 infection in hospitalized pediatric and adult patients. Science Translational Medicine, 2020; 12(564):eabd5487. https://doi.org/10.1126/scitranslmed.abd 5487

23. Rubin GJ, Potts HWW, Michie S. The impact of communications about swine flu (influenza A HiNiv) on public responses to the outbreak: Results from 36 national telephone surveys in the UK. Health Technology Assessment, 2010; 14(34):183. https://doi.org/10.3310/hta14340-03

24. Lauretani F, Ravazzoni G, Maggio M. Assessment and treatment of older individuals with COVID-19 multisystem disease: clinical and ethical implications. Acta Biomed, 2020; 91(2):150. https://doi.org/10.23750/abm.v91i2.9629
Cite this article as:

Lawrence AJ, Fatima U, Abraham A, Ali F, Arif S, Khan T. Diversified Impact of COVID-19 Pandemic on the Overall Health and Well-Being of Children: A Survey Based Case Study. Int Healthc Res J. 2021;5(6)OR1-OR9. https://doi.org/10.26440/IHRJ/0506.09454 